pruritus recurred within two and six weeks and was associated with reduced mean corpuscular volume $(<75 \mathrm{fl})$ and serum ferritin concentrations $(<20 \mu \mathrm{g} / \mathrm{l})$. Iron treatment was restarted and continued for only two to four weeks after the pruritus had cleared.

\section{Discussion}

Pruritus occurs in up to $60 \%$ of patients with polycythaemia vera. ${ }^{1}$ Classically it is aggravated by hot baths, and in some patients it interferes substantially with either sleep or daytime activities during summer. There appears to be no real correlation between the severity of polycythaemia vera and the itching. Histamine has long been regarded as a major mediator of this symptom, ${ }^{5}$ but the failure of histamine antagonists to control pruritus in most patients, together with the presence of hyperhistaminaemia in the absence of pruritus in other disorders, ${ }^{5}$ suggest that other factors play a part. Iron deficiency has been cited as a cause of generalised pruritus ${ }^{6}{ }^{7} ;$ and some degree of iron deficiency, shown by absent marrow iron, is almost universal in polycythaemia vera. ${ }^{3}$ Surprisingly, however, iron deficiency is not mentioned in any report as a possible cause for the pruritus in this disease.

In two previous reports examining the association of iron deficiency and pruritus ${ }^{8}{ }^{9}$ a favourable effect of iron treatment on the pruritus of two patients with polycythaemia vera was noted. These reports, however, did not give pertinent haematological details.

All six patients reported on here had documented polycythaemia vera with severe pruritus. During this period of heightened pruritus severe iron deficiency was present in all cases, and with oral iron treatment this abated over two to three weeks. In two of three patients requiring venesection because of a progressive rise in packed cell volume pruritus returned and values of haematological variables indicated iron deficiency. Treatment with iron resulted in an amelioration of this symptom. Since chronic iron treatment may result in progressive increases in the red cell mass we do not advocate indiscriminate use of iron in all patients with polycythaemia vera and pruritus. Only in those with severe symptoms and evidence for iron deficiency may iron be of help, and our current practice is to continue such treatment for only two to three weeks after the symptom has abated.

This study was supported in part by grants from the National Health and Medical Research Council of Australia.

\section{References}

1 Winkelmann RK, Muller SA. Pruritus. Ann Rev Med 1964;15:53-64.

2 Chanarin I, Szur L. Relief of intractable pruritus in polycythaemia rubra vera with cholestyramine. Br $\mathcal{F}$ Haematol 1975;29:669-70.

${ }^{3}$ Berlin NI. Diagnosis and classification of the polycythaemias. Semin Hematol 1975;12:339-51.

4 Dacie JV, Lewis SM, eds. Practical haematology. 5th ed. Edinburgh: Churchill Livingstone, 1975.

${ }^{5}$ Gilbert HS, Warner RRP, Wasserman LR. A study of histamine in myeloproliferative disease. Blood 1966;28:795-806.

6 Sneddon IB, Church RE. Practical dermatology. 2nd ed. London: Edward Arnold, 1971:125.

${ }^{7}$ Rook AJ, Wilkinson DS, Ebling FJG. Textbook of dermatology. 2nd ed. Oxford: Blackwell, 1972:1799.

${ }^{8}$ Sneddon IB, Garretts $M$. The significance of low serum iron levels in the causation of itching. In: Jadassohn W, Schirren CG, eds. Proceedings of XIII international congress of dermatology, Munich. Berlin: Springer, 1968:1061-3.

${ }^{9}$ Vickers CFH. Nutrition and the skin: iron deficiency in dermatology. In : Ledingham JCG, ed. Proceedings of tenth symposium on advanced medicine. London: Royal College of Physicians, 1974:311-5.

(Accepted 24 May 1982)

\title{
Postoperative analgesia with controlled-release morphine sulphate: comparison with intramuscular morphine
}

\author{
D FELL, A CHMIELEWSKI， G SMITH
}

\begin{abstract}
Fifty patients undergoing hysterectomy or cholecystectomy took part in a trial of postoperative analgesia provided by either intramuscular morphine or controlledrelease morphine sulphate tablets orally. Respiratory function and plasma catecholamine concentrations were measured after operation and pain was assessed by using a linear analogue scoring method. Controlledrelease morphine sulphate produced comparable pain relief with that of intramuscular morphine, and depression of respiratory function after operation was similar with the two analgesic regimens. The mean total dose of drug per patient given over $48 \mathrm{~h}$ to patients undergoing
\end{abstract}

Leicester Royal Infirmary, Leicester LE1 5WW

D FELL, FFARCS, senior registrar in anaesthesia

A CHMIELEW SKI, FFARCS, senior registrar in anaesthesia

University Department of Anaesthesia, General Hospital, Leicester LE5 4PW

G SMITH, MD, FFARCS, professor of anaesthesia hysterectomy was $115 \mathrm{mg}$ for morphine sulphate and $\mathbf{5 3}$ mg for morphine. Patients undergoing cholecystectomy received $130 \mathrm{mg}$ morphine sulphate or $76 \mathrm{mg}$ morphine. There was more sedation after operation in those patients undergoing hysterectomy who received morphine sulphate tablets.

Morphine sulphate tablets produced satisfactory postoperative analgesia compared with intramuscular morphine: both regimens were acceptable to the patients.

\section{Introduction}

Relief of postoperative pain is unsatisfactory despite vigorous attempts to apply recently developed analgesics and newer administration techniques. Epidural techniques after operation have become more popular and the administration of opiates in place of local anaesthetic drugs through the epidural catheter has provided some advantages. ${ }^{12}$ In addition, the administration of opiate analgesics by continuous intravenous infusion ${ }^{3}$ or patient-operated demand techniques ${ }^{4}$ has been advocated. These methods are relatively expensive, however, and require close supervision of the patient or the apparatus to monitor side effects or malfunction. Thus, the use of conventional intra- 
muscular opiates remains the most common method for postoperative analgesia. Most recently, the administration of buprenorphine sublingually ${ }^{5}{ }^{6}$ has gained popularity, largely because of ease of administration.

Morphine has recently become available as an oral preparation in slow-release form (MST Continus, Napp Laboratories), which achieves more sustained blood concentrations than intramuscular morphine sulphate ${ }^{7}$ and offers considerable advantages in terms of ease of administration. We compared morphine sulphate tablets in the treatment of postoperative pain with conventional intramuscular morphine administered on demand. Because of the well-recognised difficulties in quantifying pain we used respiratory function testing-an objective assessment that correlates with analgesia in the postoperative period $^{8}$-as well as linear analogue scoring.

\section{Patients and methods}

Informed consent to this study was obtained from 50 otherwise healthy patients undergoing hysterectomy (38 patients) or cholecystectomy (12 patients). Respiratory function tests were performed before operation by using the Gould-Godard expirograph and functional residual capacity computer. Measurements were made with the patient in a sitting position and forced expiratory volume in $1 \mathrm{~s}\left(\mathrm{FEV}_{1}\right)$, functional residual capacity (FRC), and peak expiratory flow rate (PEFR) were recorded. A sample of venous blood was obtained and analysed for baseline concentrations of noradrenaline and adrenaline using high-performance liquid chromatography. ${ }^{9}$

All patients received a standard premedication and anaesthetic technique. Diazepam 10-20 mg was given orally one and a half hours before operation, and general anaesthesia was induced by using intravenous thiopentone, maintained with nitrous oxide in oxygen and supplemented with intravenous morphine $10 \mathrm{mg}$. Volatile agents were not used. Intermittent positive-pressure ventilation was used with a non-depolarising muscle relaxant.

TABLE I-Details of patients studied. Results are means $\pm S E M$

\begin{tabular}{|c|c|c|c|c|c|c|}
\hline & No & $\underset{\text { (years) }}{\text { Age }}$ & & $\begin{array}{l}\text { Sex } \\
1 \mathrm{~F}\end{array}$ & $\underset{(\mathrm{cm})}{\text { Height }}$ & $\begin{array}{l}\text { Weight } \\
(\mathrm{kg})\end{array}$ \\
\hline $\begin{array}{l}\text { Patients after hysterectomy: } \\
\text { Morphine sulphate tablets } \\
\text { Morphine } \\
\text { Patients after cholecystectomy: }\end{array}$ & $\begin{array}{l}21 \\
17\end{array}$ & $\begin{array}{l}41 \cdot 5 \pm 1 \cdot 2 \\
37 \cdot 3 \pm 1 \cdot 7\end{array}$ & & $\begin{array}{l}21 \\
17\end{array}$ & $\begin{array}{l}164 \cdot 2 \pm 1 \cdot 4 \\
161 \cdot 2 \pm 2 \cdot 1\end{array}$ & $\begin{array}{l}65 \cdot 9 \pm 2 \cdot 7 \\
62 \cdot 1 \pm 2 \cdot 5\end{array}$ \\
\hline $\begin{array}{l}\text { Morphine sulphate tablets } \\
\text { Morphine }\end{array}$ & $\begin{array}{l}5 \\
7\end{array}$ & $\begin{array}{l}50 \cdot 8 \pm 5 \cdot 3 \\
42 \cdot 1 \pm 5 \cdot 5\end{array}$ & $\begin{array}{l}2 \\
1\end{array}$ & $\begin{array}{l}3 \\
6\end{array}$ & $\begin{array}{l}168 \cdot 8 \pm 4 \cdot 0 \\
157 \cdot 3 \pm 1 \cdot 9\end{array}$ & $\begin{array}{l}72 \cdot 6 \pm 2 \cdot 8 \\
59 \cdot 8 \pm 3 \cdot 0\end{array}$ \\
\hline
\end{tabular}

TABLE II-Linear analogue pain scores (on scale of 0-10, 0 representing no pain, 10 maximum pain) in patients 24 and 48 hours after operation. Results are means $\pm S E M$

\begin{tabular}{|c|c|c|c|c|}
\hline & \multicolumn{2}{|c|}{ Patients after hysterectomy } & \multicolumn{2}{|c|}{ Patients after cholecystectomy } \\
\hline & $\begin{array}{l}\text { Morphine sulphate } \\
\text { tablets }(n=21)\end{array}$ & $\begin{array}{c}\text { Intramuscular } \\
\text { morphine } \\
(\mathrm{n}=17)\end{array}$ & $\begin{array}{l}\text { Morphine sulphate } \\
\text { tablets }(n=5)\end{array}$ & $\begin{array}{c}\text { Intramuscular } \\
\text { morphine } \\
(\mathrm{n}=7)\end{array}$ \\
\hline $\begin{array}{l}\text { Day } 1 \\
\text { Day } 2\end{array}$ & $\begin{array}{l}3.8 \pm 0.5 \\
2.8 \pm 0.5\end{array}$ & $\begin{array}{l}3.9 \pm 0.6 \\
3.9 \pm 0.6\end{array}$ & $\begin{array}{l}3.5 \pm 0.9 \\
3.0 \pm 0.5\end{array}$ & $\begin{array}{l}4 \cdot 9 \pm 1 \cdot 5 \\
4 \cdot 9 \pm 1 \cdot 3\end{array}$ \\
\hline
\end{tabular}

All patients were allocated at random to receive either intramuscular morphine or morphine sulphate tablets for postoperative analgesia. Those patients weighing less than $70 \mathrm{~kg}$ received $10 \mathrm{mg}$ intramuscular morphine or $20 \mathrm{mg}$ morphine sulphate tablets, those $70 \mathrm{~kg}$ or heavier $15 \mathrm{mg}$ intramuscular morphine or $30 \mathrm{mg}$ morphine sulphate tablets. For both routes, morphine was given by the nursing staff as required in the conventional manner, since duration of action of morphine sulphate tablets in postoperative use had not been established.

Patients were assessed about 24 and $48 \mathrm{~h}$ after operation. Pain was assessed subjectively by a linear analogue method using a $10 \mathrm{~cm}$ line where zero represented no pain and $10 \mathrm{~cm}$ represented the maximum conceivable pain. ${ }^{10}$ Linear analogue scores were also obtained for sedation, nausea, and dizziness. Testing was timed to coincide so far as possible with the midpoint of the interval between analgesic administration and the subjective quality assessed for that time. Pulmonary function tests were performed in the same manner as before operation with the patients in a sitting position, and venous blood samples were obtained for measurement of catecholamine concentrations.

Wilcoxon's rank sum test was used for linear analogue scores. Other results were analysed by using Student's $t$ test.

\section{Results}

Table I shows the physical characteristics of the two patient groups.

There were no significant differences in pain scores in either group of the patients receiving intramuscular morphine and those receiving morphine sulphate tablets (table II).

Table III shows the depression of respiratory function after operation compared with before. There was a small but non-significant difference in the extent of depression of $\mathrm{FEV}_{1}$ produced by intramuscular morphine in comparison with morphine sulphate tablets, but FVC was significantly more depressed after operation by intramuscular morphine than by morphine sulphate tablets in the cholecystectomy group on day 1 .

Table IV shows the plasma catecholamine concentrations measured before and after operation. There was a significant increase in plasma noradrenaline concentration after operation for each analgesic in the hysterectomy group. Plasma adrenaline concentration was increased on the first postoperative day only in patients undergoing hysterectomy. In the cholecystectomy group there was only a small non-significant change. There was no significant difference between the two analgesics in respect of plasma adrenaline concentration.

Linear analogue scores for nausea or dizziness were similar for both analgesics. Morphine sulphate tablets produced significantly more sedation on both day 1 and day 2 in patients after hysterectomy than intramuscular morphine (table V).

The mean total dose of morphine received by patients undergoing hysterectomy over the first $48 \mathrm{~h}$ after operation was $53 \mathrm{mg}$ for intramuscular morphine and $115 \mathrm{mg}$ for morphine sulphate tablets. For patients undergoing cholecystectomy the mean total dose in $48 \mathrm{~h}$ was $76 \mathrm{mg}$ for intramuscular morphine and $130 \mathrm{mg}$ for morphine sulphate tablets.

A questionnaire designed to assess patient acceptability of analgesia ${ }^{6}$ showed an equal degree of satisfaction with each mode of treatment.

\section{Discussion}

This study has shown that morphine sulphate tablets produced satisfactory postoperative analgesia after hysterectomy

TABLE III-Decrease in results of pulmonary function tests (expressed as percentage of preoperative values) in patients 24 and 48 hours after operation. Results are means $\pm S E M$

\begin{tabular}{|c|c|c|c|c|c|c|}
\hline & \multicolumn{2}{|c|}{ Forced expiratory volume in $1 \mathrm{~s}$} & \multicolumn{2}{|c|}{ Forced vital capacity } & \multicolumn{2}{|c|}{ Peak expiratory flow rate } \\
\hline & Day 1 & Day 2 & Day 1 & Day 2 & Day 1 & Day 2 \\
\hline $\begin{array}{l}\text { Patients after hysterectomy: } \\
\text { Morphine sulphate tablets } \\
\text { Intramuscular morphine } \\
\text { Patients after cholecystectomy: }\end{array}$ & $\begin{array}{l}22 \cdot 7 \pm 3 \cdot 6 \\
28 \cdot 3 \pm 4 \cdot 5\end{array}$ & $\begin{array}{l}14 \cdot 7 \pm 6 \cdot 3 \\
18 \cdot 2 \pm 3 \cdot 9\end{array}$ & $\begin{array}{l}20 \cdot 3 \pm 3 \cdot 4 \\
28 \cdot 8 \pm 4 \cdot 0\end{array}$ & $\begin{array}{l}18 \cdot 1 \pm 4 \cdot 0 \\
18 \cdot 3 \pm 3 \cdot 4\end{array}$ & $\begin{array}{l}24 \cdot 7 \pm 3 \cdot 7 \\
32 \cdot 1 \pm 7 \cdot 4\end{array}$ & $\begin{array}{l}15 \cdot 3 \pm 6 \cdot 1 \\
27 \cdot 1 \pm 5 \cdot 5\end{array}$ \\
\hline $\begin{array}{l}\text { Morphine sulphate tablets } \\
\text { Intramuscular morphine }\end{array}$ & $\begin{array}{l}45 \cdot 2 \pm 7 \cdot 3 \\
56 \cdot 0 \pm 5 \cdot 5\end{array}$ & $\begin{array}{l}38 \cdot 3 \pm 5 \cdot 2 \\
49 \cdot 5 \pm 5 \cdot 5\end{array}$ & $\begin{array}{l}45 \cdot 3^{*} \pm 4 \cdot 9 \\
59 \cdot 2 \pm 3 \cdot 8\end{array}$ & $\begin{array}{l}40 \cdot 3 \pm 4 \cdot 9 \\
52 \cdot 5 \pm 4 \cdot 2\end{array}$ & $\begin{array}{l}31 \cdot 7 \pm 11 \cdot 1 \\
46 \cdot 9 \pm 11 \cdot 2\end{array}$ & $\begin{array}{l}26 \cdot 9 \pm 7 \cdot 9 \\
36 \cdot 8 \pm 12 \cdot 4\end{array}$ \\
\hline
\end{tabular}

*p $<0.05$ comparing morphine sulphate tablets with intramuscular morphine. 
TABLE IV-Plasma catecholamine concentrations before operation and 24 and $48 \mathrm{~h}$ after operation in patients undergoing hysterectomy and cholecystectomy

\begin{tabular}{|c|c|c|c|c|c|c|}
\hline & \multicolumn{3}{|c|}{ Patients undergoing hysterectomy } & \multicolumn{3}{|c|}{ Patients undergoing cholecystectomy } \\
\hline & Before operation & Day 1 & Day 2 & Before operation & Day 1 & Day 2 \\
\hline Morphine sulphate tablets & $\begin{array}{c}1 \cdot 50 \pm 0 \cdot 16 \\
(\mathrm{n}=21)\end{array}$ & $3 \cdot 12^{* *} \pm 0.32$ & $2 \cdot 41^{* *} \pm 0.26$ & \multirow{2}{*}{$\begin{aligned} 2 \cdot 16 & =0.53 \\
(\mathrm{n} & =5) \\
1.78 & \pm 0.33 \\
(\mathrm{n} & =7)\end{aligned}$} & $3 \cdot 09 \pm 0 \cdot 63$ & $3 \cdot 69 \pm 0 \cdot 85$ \\
\hline Intramuscular morphine & $\begin{array}{c}1 \cdot 30 \pm 0 \cdot 11 \\
(\mathrm{n}=17)\end{array}$ & $3 \cdot 20^{* *} \pm 0 \cdot 44$ & $3.00^{* *} \pm 0.65$ & & $2 \cdot 43 \pm 0 \cdot 63$ & $1 \cdot 77 \pm 0 \cdot 30$ \\
\hline Total & $\begin{array}{c}1 \cdot 41 \pm 0 \cdot 10 \\
(\mathrm{n}=38)\end{array}$ & $3 \cdot 16 * * 0 \cdot 26$ & $2 \cdot 67 * * 0 \cdot 32$ & $\begin{array}{c}1 \cdot 84 \pm 0 \cdot 30 \\
(\mathrm{n}=12)\end{array}$ & $2 \cdot 73 \pm 0.44$ & $2.73 \pm 0.53$ \\
\hline Morphine sulphate tablets & $\begin{array}{c}0 \cdot 18 \pm 0 \cdot 02 \\
(\mathrm{n}=21)\end{array}$ & $0.26 \quad 0.05$ & $\begin{aligned} & \text { Adre } \\
& 0.20 \pm 0.03\end{aligned}$ & $\begin{array}{c}(\mathrm{nmol} / \mathrm{l}) \\
0 \cdot 26 \pm 0.03 \\
(\mathrm{n}=5)\end{array}$ & $0 \cdot 25 \pm 0.04$ & $0.30 \pm 0.03$ \\
\hline Intramuscular morphine & $\begin{array}{c}0.21 \pm 0.03 \\
(\mathrm{n}=17)\end{array}$ & $0.26 \pm 0.03$ & $0.25 \pm 0.04$ & $\begin{array}{c}0 \cdot 16 \pm 0.03 \\
(\mathrm{n}=7)\end{array}$ & $0 \cdot 37 \pm 0 \cdot 14$ & $0 \cdot 14 \pm 0 \cdot 04$ \\
\hline Total & $\begin{array}{c}0 \cdot 19 \pm 0 \cdot 02 \\
(\mathrm{n}=38)\end{array}$ & $0.26^{*} \pm 0.03$ & $0.22 \pm 0.03$ & $\begin{array}{c}0 \cdot 20 \pm 0.03 \\
(\mathrm{n}=12)\end{array}$ & $0.33 \pm 0.09$ & $0.21 \pm 0.04$ \\
\hline
\end{tabular}

${ }^{*} \mathrm{p}<0.05 .^{* *} \mathrm{p}<0.01$

Conversion: SI to traditional units-Noradrenaline: $1 \mathrm{nmol} / 1 \approx 0.17 \mathrm{mg} / 100 \mathrm{ml}$. Adrenaline: $1 \mathrm{nmol} / 1 \approx 0.18 \mathrm{mg} / 100 \mathrm{ml}$.

TABLE V-Linear analogue scores for sedation (on scale of 0-0, 10 representing no sedation and 10 maximum sedation) 24 and 48 h after operation

\begin{tabular}{|c|c|c|c|c|}
\hline & \multicolumn{2}{|c|}{ Patients after hysterectomy } & \multicolumn{2}{|c|}{ Patients after cholecystectomy } \\
\hline & $\begin{array}{c}\text { Morphine sulphate } \\
\text { tablets }(n=21)\end{array}$ & $\begin{array}{c}\text { Intramuscular } \\
\text { morphine } \\
(\mathrm{n}=17)\end{array}$ & $\begin{array}{l}\text { Morphine sulphate } \\
\text { tablets }(n=21)\end{array}$ & $\begin{array}{c}\text { Intramuscular } \\
\text { morphine } \\
(\mathrm{n}=17)\end{array}$ \\
\hline $\begin{array}{l}\text { Day } 1 \\
\text { Day } 2\end{array}$ & $\begin{array}{l}7 \cdot 5^{* *} \pm 0 \cdot 5 \\
4 \cdot 6^{* *} \pm 0 \cdot 7\end{array}$ & $\begin{array}{l}5 \cdot 0 \pm 0 \cdot 7 \\
2 \cdot 0 \pm 0.5\end{array}$ & $\begin{array}{l}4 \cdot 0 \pm 0 \cdot 9 \\
2 \cdot 8 \pm 1 \cdot 3\end{array}$ & $\begin{array}{l}5 \cdot 6 \pm 1 \cdot 1 \\
3 \cdot 8 \pm 1 \cdot 4\end{array}$ \\
\hline
\end{tabular}

$* * \mathrm{p}<0.01$ comparing morphine sulphate tablets and intramuscular morphine.

and cholecystectomy compared with that produced by the conventional intramuscular morphine regimen, as assessed by subjective linear analogue scoring. This is confirmed by the slightly smaller depression of FVC produced by morphine sulphate tablets compared with that produced by morphine. As expected, there was a correlation between depression of respiratory function tests and linear analogue pain scores after operation.

Until now, morphine sulphate tablets have been used primarily to provide analgesia for the pain of advanced cancer and satisfactory results have been obtained by using $10 \mathrm{mg}$ tablets (R G Twycross, S D Fairfield, personal communication). Recently, Hanks et al ${ }^{11}$ used morphine sulphate tablets unsuccessfully for relief of postoperative dental pain, but they did not use a loading dose intravenously as we did. In addition, it is likely that higher and more sustained plasma concentrations were achieved in our study as a result of frequent postoperative administration (inspection of prescription sheets showed that morphine sulphate $20 \mathrm{mg}$ tablets were given almost regularly every six hours). Bercowitz ${ }^{12}$ has suggested that morphine concentrations in plasma of $50 \mu \mathrm{g} / 1$ are required for analgesia, though there are limitations in such a statement because of considerable individual variation..$^{13}$ This concentration is attained by intramuscular morphine in a dose of $10 \mathrm{mg} / 70 \mathrm{~kg},{ }^{13}$ and by morphine sulphate tablets $20 \mathrm{mg} .{ }^{6}$ In our study, a dose of morphine sulphate tablets of $30 \mathrm{mg}$ was given to patients exceeding $70 \mathrm{~kg}$ bodyweight and this may have contributed to the more successful analgesia in this study.

The frequency of nausea and dizziness was similar for both analgesic regimens, but morphine sulphate tablets appeared to make patients much more sleepy than intramuscular morphine. Both regimens, however, proved equally acceptable to the patients.

Because of the loss of morphine owing to first-pass metabolism after oral ingestion and absorption, it has been suggested that the potency ratio of morphine sulphate tablets to intramuscular morphine is approximately 1 to 2 . This is supported by our findings that about twice the dose of the oral drug was administered by the nursing staff at their own discretion and the assessment of the patient compared with the intramuscular form.
A greater advantage theoretically to the regular oral administration of morphine sulphate tablets is the likelihood of less fluctuation in plasma morphine concentrations, and this warrants further pharmacokinetic studies (currently in progress). Plasma catecholamine concentrations were measured in this study in an attempt to measure the extent of postoperative stress by an objective index. The catecholamine response to intraoperative stress may be blocked by the use of large doses of narcotic analgesics. ${ }^{14}$ There was no correlation, however, between the increase in plasma catecholamine concentrations after operation and the linear analogue pain scores. This suggests that the rise of catecholamine concentrations after operation is produced by several factors in addition to pain.

This work was supported by a grant from the Trent Regional Health Authority.

\section{References}

${ }^{1}$ Reiz S, Ahlin J, Ahrenfeldt B, Andersson M, Andersson S. Epidural morphine for postoperative pain relief. Acta Anaesthiol Scand 1981; 25:111-4.

2 Rutter DV, Skewes DG, Morgan M. Extradural opioids for postoperative analgesia. Br $\mathcal{F}$ Anaesth $1981 ; 53: 915-9$.

${ }^{3}$ Church JJ. Continuous narcotic infusion for the relief of postoperative pain. Br Med f 1979; : $977-9$.

4 White WD, Pearce DJ, Norman J. Postoperative analgesia: a comparison of intravenous on-demand fentanyl with epidural bupivacaine. $\mathrm{Br} \mathrm{Med} \mathcal{F}$ 1979 ;ii:166-7.

${ }^{5}$ Fry ENS. Relief of pain after surgery. A comparison of sublingual buprenorphine and intramuscular papareveretum. Anaesthesia 1979;34:54951.

${ }^{6}$ Ellis R, Haines D, Shah R, Cotton BR, Smith G. Pain relief after abdominal surgery - a comparison of im morphine, sublingual buprenorphine and self-administered iv pethidine. $B r \mathcal{F}$ Anaesth 1982 (in press).

${ }^{7}$ Leslie ST, Rhodes A; Black FM. Controlled release morphine sulphate tablets-a study in normal volunteers. Br $\mathcal{F}$ Clin Pharmacol 1980;9: 531-4.

8 Bromage PR, Camporesi E, Chestnut D. Epidural narcotics for postoperative analgesia. Anesth Analg (Cleve) 1980;59:473-80.

9 Fell D, Achola K, Smith G. Plasma catecholamines in anaesthesia. $\mathrm{Br} \mathcal{F}$ Anaesth 1982;54:231P.

${ }^{10}$ Revill SI, Robinson JO, Rosen M, Hogg MIJ. The reliability of a linear analogue for evaluating pain. Anaesthesia 1976;31:1191-8.

11 Hanks GW, Rose NM, Aherne GW, Piall EM, Fairfield S, Trueman T. Controlled release morphine tablets-a double-blind trial in dental patients. Br $\mathcal{F}$ Anaesth $1981 ; 53: 1259-63$.

12 Bercowitz BA, Ngai SH, Yang JC, Hampstead J, Spector S. The disposition or morphine in surgical patients. Clin Pharmacol Ther $1975 ; 17: 629-35$.

13 Bercowitz BA. The relationship of pharmacokinetics to pharmacological activity: morphine, methadone and naloxone. Clin Pharmacokinet 1976; 1:219-30.

14 Stanley TH, Berman L, Green O, Robertson D. Plasma catecholamine and control responses to fentanyl-oxygen anesthesia for coronary artery operations. Anesthesiology 1980;53:250-3.

(Accepted 26 May 1982) 